\title{
Banking Governance: What's Special About Islamic Banks?
}

Faten Ben Bouheni, ISC Paris Business School, LITEM research laboratory - France Chantal Ammi, TELECOM Business School, LITEM research laboratory - France

\begin{abstract}
ABTRACT
Recent turmoil and financial institutions' failures in the U.S and in the EU have led to a renewed interest in corporate governance. Thus, the ultimate decisions taken to out of the crisis were to review the mechanisms of banking governance. The Islamic banking may use the same governance mechanisms as a conventional bank, in addition to the Shariah boards, the Shariah review unit, the Islamic International Rating Agency (IIRA) and, the Islamic Financial Services Board (IFSB) like main bodies of monitoring the Islamic Banking industry. In contrast to the conventional banks, the Islamic banks are based on the active participation of public policy institutions, regulatory and supervisory authorities, and Shariah authorities. These institutions collectively monitor the performance of the firm and its faithfulness and commitment to explicit as well as implicit contracts ${ }^{l}$. Islamic banking designates banking activities, which are conforming to Islamic law (Shariah) and guided by Islamic economics. In particular, Islamic law prohibits usury and payment of interest (Riba), it also prohibits investing in businesses that are considered unlawful. And the competitiveness of many of Islamic products and the PLS principle attract Muslim and non-Muslim investors.
\end{abstract}

Keywords: Banking Corporate Governance; Islamic Banking; Conventional Banking

\section{INTRODUCTION}

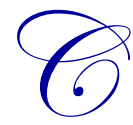

orporate governance has become one of the most debated subjects, especially in the banking environment, as a consequence of the recent financial crisis that spread all over the world (Ben Bouheni, 2013). During the subprime crisis of 2007/2008, it not only hit the U.S economy, but also triggered the global financial tsunami and the financial market turmoil. In fact, this crisis made from corporate governance a crucial economic concept, bringing it as well to the attention of media, academic and political environments and, thereby becoming the most rigorous topic of worldwide research. Corporate governance represents a set of instruments that impact how a corporation is operated. It deals with the welfare of all the stakeholders and the economy as a whole. The aim of corporate governance is to achieve the best overall welfare for all stakeholders and promote economic performance. Adams et al. (2010) argue that the firm confronts a myriad governance's problems; and that its governance structure emerges as its best response to those problems. Thus, given the heterogeneity of governance issues faced by the firm, it is unlikely that a unique governance policy is the best for all firms.

In this paper, we review the theoretical and empirical research on the main mechanisms of banking corporate governance, the features of Islamic banks and their problems and, we propose some recommendations. Banks differ from other financial firms because of the opacity and the nature of their activities, they act as intermediaries and provide liquidity. Banks require a system for processing the debits and credits arising from these banking transactions. The payment system is a derivative of intermediation and facilitates the transfer of ownership claims in the financial industry (Ben Bouheni, 2014b). Banks are the engines of the economy and, their bankruptcy fragilizes all the economic system. These strong externalities in the economy make the corporate governance of banks a fundamental issue. Well-governed banks will be more competent in their functions than those governed poorly (Levine, 2004). We focus on Islamic banking, seeing that Islamic finance is a fast-growing sector of the

\footnotetext{
${ }^{1}$ See Ben Bouheni (2014a), Banking Governance: Islamic banks vs. Conventional banks", Hanken Centre For Corporate Governance, Finland,
} 26th February 2014. https://www.shs.fi/banking-governance-islamic-banks-vs-conventional-banks-262-1630-1800 
global banking industry and, that there are many banks that supply Islamic financial products and services around the world including well-known institutions. Moreover, Islamic banks are better capitalized, have higher asset quality and are less weakened by the crises. Beck et al. (2013) show that the better stock performance of listed Islamic banks during the recent crisis is due to their higher capitalization and better asset quality. It may be necessary to study the features of Islamic banking governance. Furthermore, the question arises as to whether banks are different from other corporations. Banks appear with new questions to the corporate governance problem due to their specific characteristics and their regulated condition. Our paper can be briefly summarized around the following main issues:

- Why has the banking corporate governance become more important?

- What is special about Islamic banking corporate governance?

- How are Islamic banking governance mechanisms different from those of conventional banking?

The rest of the paper is organized as following: section (1) Banking corporate governance; section (2) Features of Islamic banking; and section (3) Mechanisms of Islamic banking governance.

\section{E-BANKING CORPORATE GOVERNANCE}

The most quoted definition of corporate governance is the one given by Shleifer and Vishny (1997): "Corporate governance deals with the ways in which suppliers of finance to corporations assure themselves of getting a return on their investment. The corporate Governance deals with the agency problem: the separation of management and finance, the fundamental question of Corporate Governance is how to assure financiers that they get a return on their financial investment". In their survey, Shleifer and Vishny (1997) account for different governance models across countries especially those of US, UK, Germany, and Japan. They conclude that the United States and the United Kingdom have a governance system distinguished by a strong legal protection of investors and the lack of large investors. However, in the continental Europe as well as in Japan, the system characterized by a weak legal protection of minorities and the presence of large investors. Under a more specific definition of corporate governance, the focus would be on how outside investors protect themselves against expropriation by the insiders (large investors). Although there are myriad definitions of corporate governance, and they vary between narrow and broad perspectives, the governance may be defined as a set of internal and external mechanisms aims the harmonization between shareholders and stakeholders. It is based on the good combination between management and control in order to get a win-win relationship in which perspectives and interests are aligned and achieved.

\section{Special Nature of Banking Governance}

Corporate governance in banks plays a special role due to the special nature of these organizations. Studies on bank corporate governance (Levine, 2004; Macey and O'Hara, 2003) acknowledge the existence of difficulties, such as opacity or complexity and regulation, in the governance of these institutions. Further, such difficulties interfere with the way in which the usual corporate governance mechanisms are applied to the governance of financial institutions. Adams and Mehran (2003) and, Macey and O'Hara (2003) find systematic differences between the governance of banking and manufacturing firms and highlight the point that governance structures are industry specific. The problem of bank governance does not differ greatly from the governance problem of any organization whose business involves an exchange of goods. The debate on the corporate governance of banks can be included in the more general attempts to answer the basic question: are banks special? In 1985, Fama wrote a famous article with the title: "What's different about banks?" This issue is still today a much-debated question and the answer to this question has a strong impact on which financial regulation arrangement to choose. The Corporate governance of banks affects the value of banks, their cost of capital, their performance, their strategic decisions, and their risk management. Formal econometric studies show that banks exert a strong impact on economic development. When banks efficiently mobilize and allocate funds, this lowers the cost of capital to firms, boosts capital formation and, stimulates productivity growth (Levine 2004, 2007). Since banks exert corporate governance on firms, as creditors of firms and as equity holders, the corporate governance of banks becomes crucial for financial growth and economic development. Despite the importance of this topic, there are only a few studies on the corporate governance of banks. 


\section{FEATURES OF ISLAMIC BANKING}

Unlike conventional banks, Islamic banks are not authorized to charge interest by lending money to their customers because, under Islamic law (Shariah), making money from money (Riba) is rigorously prohibited. In contrast, conventional banks charge interest on loans made to customers and pay interest on customers' deposits. The bank charges a higher rate of interest on loans made than it pays on deposits so it earns a profit from the spread between the interest rate on its assets and the rate on its liabilities (Ben Bouheni and Bellalah, 2012). Islamic banking assets with commercial banks grew to $\$ 1.3$ trillion in 2011, suggesting an average annual growth of $19 \%$ over past four years ( $24 \%$ in 2011). The top markets account for $84 \%$ of industry assets. The Islamic banking growth story continues to be positive, growing $50 \%$ faster than the overall banking sector. Referring to Ernst \&Young Report (2013), high potential international markets - each in different stages of development and therefore requiring different penetration strategies - include Saudi Arabia, Malaysia, Qatar, Turkey and Indonesia. Figure 1 shows global banking assets with commercial banks to reach $\$ 1.8$ trillion in 2013 (2011: \$1.3 trillion), representing average annual growth of $17 \%$.

Figure 1. Islamic Banking Asset Growth

Islamic banking asset growth (US\$b)

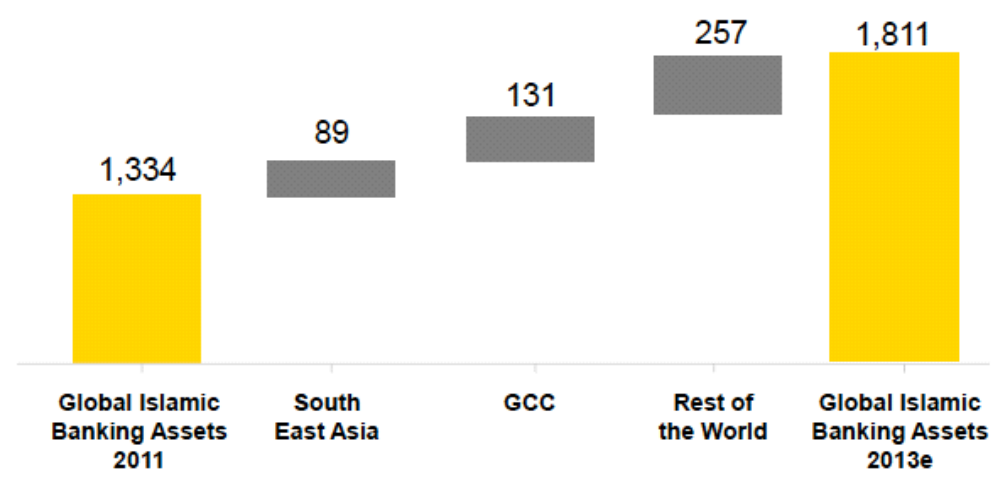

Source: IMF, The Banker, Central Bank Reports, EY Universe (2013)

Figure 2. Islamic Banking Assets Trend

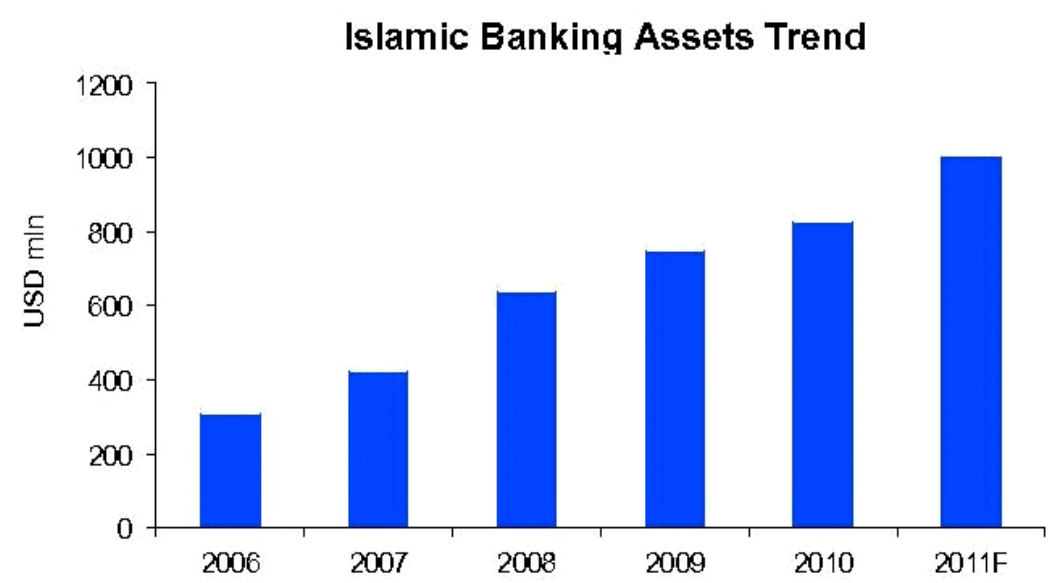

Source: Bloomberg, UN, CIA Factbook, The Asian Banker, EY, KFHR (2011) 
Figure 3. Global Islamic Funds Industry (2003-2013)

\section{Global Islamic Funds Industry (2003-2013F)}

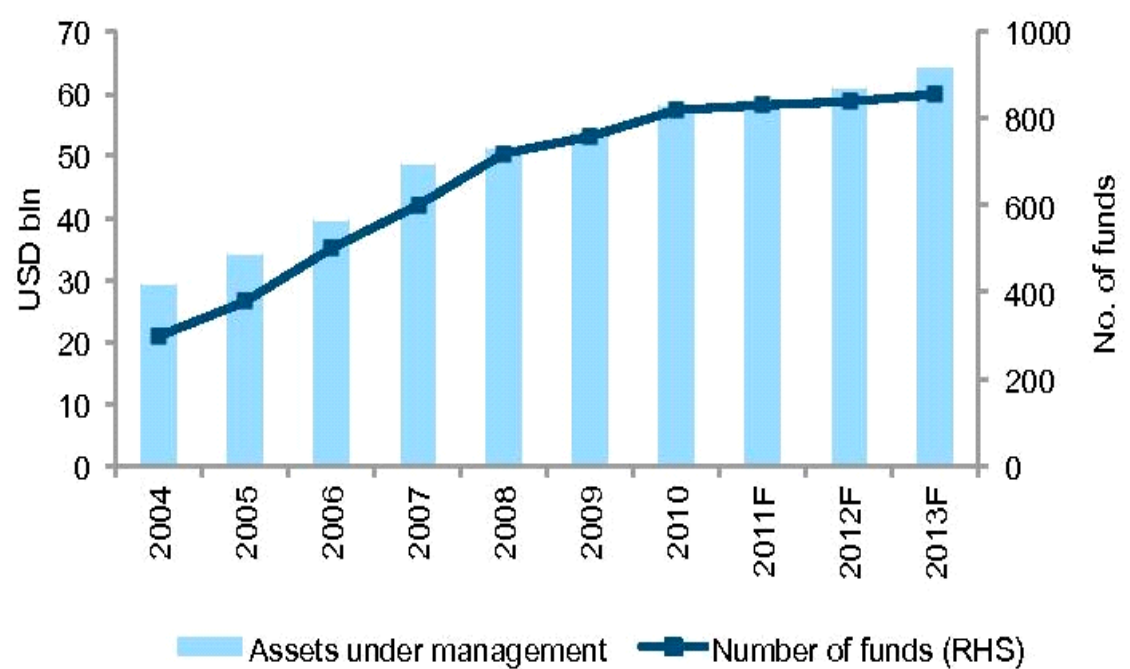

Source: Bloomberg, UN, CIA Factbook, The Asian Banker, EY, KFHR (2011)

Islamic banking assets worldwide have grown at more than $10 \%$ annually over the past ten years, from about USD 150bln in the mid-1990s to a forecast of USD 1th in 2011 (see Figure 2). Also, the value of assets managed by Islamic banks is expected to grow to USD 4 th by 2020. Many European municipalities and governments are dealing with Islamic banking products, mainly bonds (Sukuk). In Asia, many countries have Islamic banks and finance companies. Malaysia is known by its pioneering and its most sophisticated Islamic banking industries in the world. The United Kingdom, where the Muslim population is three times less than in France, is home to five Islamic banks, the only licensed ones in the European Union, and lists £5.5bn in sukuk, or Islamic bonds, on its stock exchange. Arnaud (2010) notices that, since 2003, the United Kingdom has been reforming laws to ensure that Shariah-compliant investments are not prone to higher levies than their conventional equivalents. Up to 2008 in France, and although some financial institutions seem to be willing now to enter into a licensing process for this purpose, the development of Islamic finance has concerned essentially investment banking, but this situation could evolve only a handful of French banks, such as BNP Paribas and Société Générale currently offer wholesale Islamic services. These services are labeled "Islamic windows." These windows have a crucial contribution to develop the Islamic finance, although the French Islamic windows do not provide retail products at all. However, France is taking a significant step towards establishing Paris as a western center for Islamic finance (Arnaud, 2010). France's goals are to attract global funds, and, particularly, to make France more competitive in the area of Islamic finance since France is an international finance center. 
Figure 4. Breakdown of Shariah-compliant assets worldwide

\section{Breakdown of Shari'ah-Compliant Assets Worldwide \\ (2011E)}

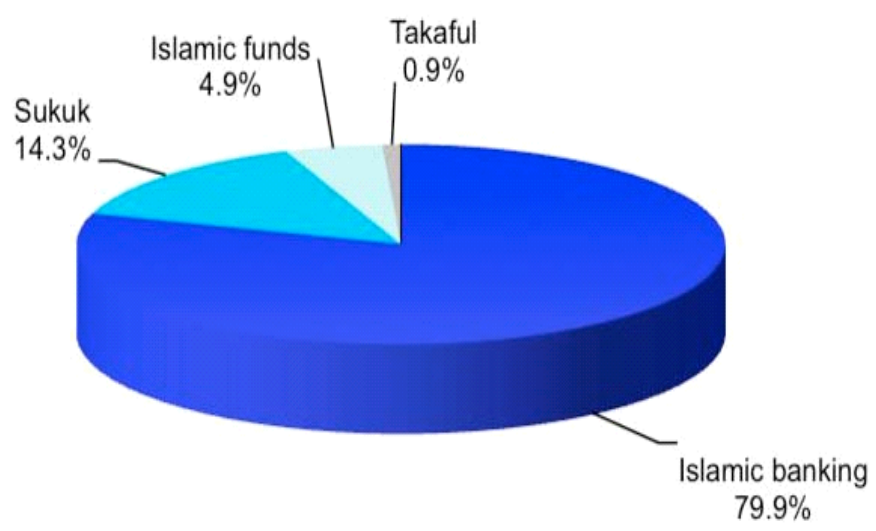

Source: Bloomberg, UN, CIA Factbook, The Asian Banker, EY, KFHR (2011)

\section{Principles of Islamic Financial System}

The Islamic financing system is based on the framework given by the Shariah. Shariah is the rules and principals that are emanated from the Quran and Sunnah ${ }^{2}$. Islamic scholars also elaborated the Islamic rules in Islamic jurisprudence according to the frame of Quran and Sunnah. The main features of Islamic financial system are the followings:

\section{Prohibition of Interest}

An Islamic Financial System strictly prohibits Riba, a term literally means "an excess" and interpreted as "any unjustifiable increase of capital whether in loans or sales"; and this rejection of Riba is the main belief in the Islamic financial system. Riba is defined as "Regardless of the performance of any investment a fixed positive rate of return applied to the maturity of any amount".

\section{Profit - Loss Sharing (PLS)}

In an Islamic financing system, the provider of the finance or capital and the entrepreneur undertake projects and, they share the profits and the business risk. Shariah prohibits Muslims from earning income by charging interest but permits income generation through the sharing of risks and rewards (mudharabah) between the parties to a transaction. This profit-sharing mechanism encourages people to become partners and work together rather than to enter into accreditor-debtor relationship. The partnership promotes mutual responsibility for the outcome of the financed project, which is believed to increase the likelihood of success of the venture. Shanmugam and Rina (2009) show that the partnership aims to increase successful projects that provide stimulus to the economy.

\section{Prohibition of Speculative Behavior}

An Islamic financial system is against hoarding and does not approve transactions that are uncertain in nature or which comprise gambling and risks.

\footnotetext{
${ }^{2}$ Sunnah is the elaboration and the explanation by the Prophet Muhammad PBUH 


\section{Sanctity of Contracts}

In the Islamic Financial system implementation of contractual obligations that should be explicitly mentioned in written form and disclosure of relevant information, is of paramount importance in order to reduce the risk of asymmetric information and moral hazard. In order to validate a contract some conditions are required: a competent understanding of the underlying asset(s) and the profit-sharing ratio, as well as the presence of a willing buyer and seller. Contracts must also not violate Islamic religious and moral principles; if they do, they will be considered illegal and unenforceable (Shanmugam and Rina, 2009).

\section{Avoidance of Gharar (excessive risk-taking)}

Shariah prohibits financial transactions that involve gharar, which is often translated as "deception," "excessive risk," or "excessive uncertainty." Examples of gharar are the sale of fish in the sea, of birds in the sky, and of unripe fruits on the tree, which cause excessive and avoidable uncertainty. Unlike riba, which involves the question of the presence or absence of interest, gharar raises the question of degree. It is not, as well, defined as riba, and a ruling of permissibility based on gharar could take into account a cost-benefit analysis. The gharar exists in contracts where the object of the sale is not in the possession of the seller or does not exist at the time. The parties enter into the contract, but such contracts are allowable.

\section{Problems of Islamic Banks and Recommendations}

In some countries, the Islamic banks suffer from different gaps mainly:

- Lack of regulatory and legislative structures: Many countries don't have operational regulations governing Islamic banks or don't have a separate code.

- Accounting problems: Islamic banks are facing accounting problems while implementing the Islamic laws according to Shariah. The Islamic financial system requires a sound accounting procedure that should be followed by all Islamic banks.

- Unskilled staff: Banks are having the problems in understanding and applying the new concepts of Islamic banking.

- Excess liquidity: The increase in the liquidity is not due to the reduced demand for credit by the customer. It is mainly because the inability of banks to get the clients and customers are not willing to fund the projects by new modes of financing, mainly because risky projects do not receive funds.

- Involvement in specialized non-bank activities: Banks invest in the profitable projects that have little risk, even non-bank activities.

- Uneasy questions of morality: The large banks can't fulfill the Shariah conditions for the mode of financing by practicing as mentioned in Shariah (different scholars and Islamic thought).

- Customer dissatisfaction: The problem lies in the service quality of these Islamic banks which is poor, not up to the expectations and not as what conventional banks provide.

- Unique product and concentrated banking: Almost all the banks are offering a similar product. Only a handful of banks have made innovation in offering new products.

- Lack of uniformity: Due to the unavailability of any universal Islamic board, each Islamic bank has made personnel Islamic guidelines to be followed. One of the reasons is the interpretation of different Islamic principles by different schools of thought regarding the new Islamic products.

- Lack of standards: The main cause of uncertainty is the lack of standard financial contracts and products. The bankers don't have the basic concept and foundation of Islamic products causes a slowdown in the development of new products.

- Vocabulary of Islamic banking: As these Islamic terms are in Arabic, so every school of thought has different interpretation of these Islamic products and;

- Lack of awareness: Due to the lack of awareness in the public, the banks are facing the problem of its acceptability in the society. 
Thus, we propose some recommendations:

- Training of banking staff: Islamic banks should get together to make training institution for the training of their employees and new staff to perform their duties very well.

- The vocabulary of Islamic banking: Different Islamic banks sometimes give the different meaning of the same product in different countries. The banks' products must have same meaning in order to achieve the comparable standards.

- Public awareness: Islamic banks should go for the proper marketing to make the public aware of these banks and Islamic products.

- Uniformity in the religious principles: All Islamic banks should get together and make a uniform council, which should define authenticated and cohesive Islamic rules for Islamic banking accepted by all banks (proper accounting standards, proper written code, etc.).

- And improvement of service quality: In order to get the large number of customers, the banks need to improve the service quality and professional behavior which will result in greater customers and reduce customer's erosion. The positive relationship between the quality of service and satisfaction of customer is getting crucial as knowledge and awareness level increases in the bank customers.

\section{MECHANISMS OF ISLAMIC BANKING GOVERNANCE}

The Islamic Bank, it may use the same mechanisms as a conventional bank, in addition to the Shariah boards, the Shariah review unit, the IFSB and the IIRA as main mechanisms of monitoring the Islamic Banking system. Unlike the conventional system, the Islamic financial system is based on the active participation of public policy institutions, regulatory and supervisory authorities, and Shariah authorities. These institutions collectively monitor the performance of the firm and its faithfulness and commitment to explicit and implicit contracts.

\section{Shariah Boards}

A particular feature of Islamic banks is the accordance of activities with the principles of Shariah. Islamic banks have created corporate governance structures and processes to reassure stakeholders that all transactions conform to Shariah principles and to ensure compliance. Shariah supervisory boards, operating either within the Islamic bank itself or through an external institution such as the central bank, ensure conformity with religious principles. Each board has the authority to design, develop, and issue Shariah-compliant financial products and legal instruments. Shariah Boards exist in all Islamic countries with the exception of the Islamic Republic of Iran, where the central bank guarantees and monitors compliance of the whole banking system with Shariah (Greuning and Iqbal, 2008).

The internal tasks of Shariah supervisory boards vary according to the provisions stipulated in the particular Islamic bank's articles of association or by national regulators. However, a review of 13 Islamic banks for which sufficient information was available revealed that all Shariah supervisory boards are entrusted with ex-ante monitoring. Next to internal regulations, international and national regulators often implement guidelines for Shariah Boards. These refer to the liability to ensure Shariah compliance of transactions and less frequently specify competencies, composition, and decision-making authority. Shariah Boards are responsible for five main areas: certification of permissible financial instruments through fatwas (ex-ante Shariah audit), verification of transactions' compliance with issued fatwas (ex-post Shariah audit), the calculation and payment of zakat (alms giving), disposal of non-Shariah-compliant earnings and, advice on the distribution of income or expenses among the bank's shareholders and investment account holders. Each Shariah Board issues a report to certify the Shariah compliance of all financial transactions (Ben Bouheni and Bellalah, 2012).

The functioning of internal Shariah boards raises five issues for corporate governance: independence, confidentiality, competence, consistency, and disclosure: The first issue means the independence of the Shariah supervisory board from the management. Usually, members of Shariah boards are appointed by the shareholders of the bank and, represented by the board of directors. The board members' dual relationship with the Islamic bank as a provider of remunerated services and as assessor of the nature of operations can create a conflict of interest. Confidentiality issues may be intertwined with issues of independence. Many Shariah scholars sit on various boards. 
This multiple memberships may be the strength, as it may enhance independence vis-à-vis a particular Islamic bank. However, it entails access to proprietary information of different, possibly competing, Islamic banks. Thus, Shariah board members may find themselves in the midst of a potential conflict of interest. Shariah board members are required to combine a diverse set of competencies. The issue has been addressed by including members from different backgrounds on most Shariah boards. The combination of experts rather than expertise poses the challenge of overcoming different perspectives, as well as potential failures of communication. Over time, the gap between the supply of and the demand for individuals with both Shariah and financial skills is likely to narrow through public policy and formal cross-disciplinary training. The fourth issue concerns consistency of judgment across Islamic banks over time or across jurisdictions within the same Islamic bank.

The activities of Shariah boards create jurisprudence by their interpretation of legal sources. As such, it would not be surprising to find conflicting opinions on the admissibility of specific financial instruments or transactions. However, the diversity of opinion is less widespread than expected. Nevertheless, as the industry expands, the number of conflicting rulings on the permissibility of an instrument is likely to grow if no efforts are made to harmonize the standards. These conflicting rulings may undermine customer confidence in the industry and have repercussions on the enforceability of contracts. The last issue is the disclosure of all information relating to Shariah advisory. Stable corporate governance systems seek to enhance the soundness of Shariah governance. The framework is enhanced by arrangements put in place by regulators and external providers of financial information services. In addition, public rating agencies create a positive climate for Shariah compliance. Greuning and Iqbal (2008) notice that the Private rating agencies have not yet developed the important skills or found enough incentives to monitor Islamic bank compliance with the Shariah principles. "Islamic rating" has so far been the exclusive domain of government-sponsored organizations such as the International Islamic Rating Agency and the Malaysian Rating Corporation.

\section{The Shariah Review Units}

In addition to Shariah Boards, most Islamic banks, particularly those complying with standards of the Accounting and Auditing Organization for Islamic Financial Institutions (labeled AAOIFI), have established another internal Shariah review structure: the Shariah review unit. This Shariah review unit is independent of other departments and it is an integral part of the institution's audit and control department. It performs an array of tasks similar to that of the audit department where reviewers use all powers necessary to make sure that all financial transactions implemented by management comply with Shariah board rulings. In this respect, the role of the internal review unit is limited to complementary ex-post monitoring. In some instances, Shariah review units have been given exclusive responsibility for ex-post monitoring. These units face many of the same challenges as Shariah boards, in particular, regarding independence and competence.

Next to internal arrangements, the Shariah governance framework includes features put in place by regulators, such as the provision of financial information to persons outside the institution. According to Greuning and Iqbal (2008), among regulatory arrangements, centralized Shariah boards are the most noteworthy in relation to Shariah governance. While there are significant differences across countries, centralized Shariah boards focuses usually on the ex-ante monitoring, mostly understood as standardization of Shariah interpretation, and with ex-post monitoring of Shariah compliance. They emphasis also on issues related to the Shariah compliance and offer arbitration and support to the settlement of Shariah disputes among members of the Shariah Board to avoid conflicts of interests.

\section{The Islamic Financial Services Board (IFSB)}

The Islamic Financial Services Board (IFSB), based in Kuala Lumpur, was officially inaugurated on 3rd November 2002 and started operations on 10th March 2003. It serves as an international standard-setting body of regulatory and supervisory agencies that have vested interest in ensuring the soundness and stability of the Islamic financial services industry which is defined broadly to include banking, capital market and insurance. The IFSB promotes the development of a prudent and transparent Islamic financial services industry through introducing new, or adapting existing international standards consistent with Shariah principles, and recommend them for adoption ${ }^{3}$.

${ }^{3}$ For more information about the IFSB see: http://www.ifsb.org/background.php 


\section{The Islamic International Rating Agency (IIRA)}

The Islamic International Rating Agency (IIRA), which is based in Bahrain, started its activity in July 2005. It rates solvability, Shariah compliance and corporate governance of financial institutions, and also insurers' financial strength. It has to compete with the most important international rating agencies such as Fitch, Moody's, and Standard \& Poor's.

\section{CONCLUSION}

In theory, Islamic finance differs significantly from conventional finance. Specifically, Shariah-compliant finance does not allow the charging of interest payments (Riba), and it relies on profit-loss sharing (PLS) principle. There are clear differences in funding and activity structures of Islamic and conventional banks. In practice, however, Islamic scholars have developed products that match with conventional banking products, by replacing interest rate payments and discounting with fees and contingent payment structures (Beck et al. 2013). Moreover, Islamic Bank may be using the same mechanisms of governance like conventional bank; in addition to the Shariah boards, the Shariah review unit, the IFSB and the IIRA as main mechanisms of monitoring the Islamic Banking system. The goals of Islamic banks are: achievement of a pattern of growth; eradication of poverty; equitable distribution of income and wealth; and opportunities for gainful employment. Thus, this new system is based on the Shariah rules, and it aims to achieve the prosperity and the goodwill of all the Islamic community. In addition, the competitiveness of many of Islamic products and the PLS principle attract Muslim and non-Muslim investors. Unlike a conventional bank that is a borrower and lender of funds and it is guided by the "maximization of value", an Islamic bank is essentially a partner with its depositors, and also a partner with stakeholders. Thus, Islamic and conventional banks could be distinguishable on the basis of financial information obtained from company financial statements. However, all banks operate in the same competitive environment and are regulated in the same way in most countries, thereby, it is not surprising that Islamic and conventional banks exhibit some similar financial features.

\section{AUTHOR INFORMATION}

Dr. Faten Ben Bouheni is Professor of Finance at ISC Paris Business School. She is also a researcher at LITEM research laboratory in France. Her research focuses on financial institutions, mainly conventional and Islamic banks, with special emphasis on regulatory and supervisory issues. E-mail: faten.ben_bouheni@telecom-em.eu (Contact author)

Dr. Chantal Ammi is Professor of Marketing and Strategy at Telecom Business School. She is also Director of the Doctoral Program at Telecom Business School and Director of LITEM research laboratory in France. Her research focuses on international marketing, marketing of services, marketing of telecoms, global consumer behaviour and Islamic banks. E-mail: chantal.ammi@telecom-em.eu

\section{REFERENCES}

Adams, R., Mehran, H. (2003): “Is corporate governance different for bank holding companies?”, Economic Policy Review - Federal Reserve Bank of New York.

Adams, R.B., Hermalin, B.E., Weisbach, M.S. (2010) 'The Role of Boards of Directors in Corporate Governance: A Conceptual Framework and Survey '. Journal of Economic Literature 48, 58-107

Arnaud, A. (2010), "The French Licensing authority faced with globalization of Islamic Finance”, in M. F. Khan and Mario Porzio (ed), Islamic Banking and Finance in the European Union: A Challenge, Cheltenham Northampton: Edward Elgar, 167-174.

Beck, T., Demirguc-kunt, A., Merrouche, O. (2013): "Islamic vs. conventional banking: Business model, efficiency and stability", Journal of Banking and Finance 37, 433-447.

Ben Bouheni, F, (2014a): "Banking regulation and supervision: can it enhance stability of banks in Europe", Journal of Financial Economic Policy

Ben Bouheni.F. (2013): "The effects of supervision on banking performance: European evidence" International conference "Governance \& Control in Finance \& Banking: A New Paradigm for Risk \& Performance" 
Paris, France, April 18-19, 2013. http://www.virtusinterpress.org/IMG/pdf/Faten Ben Bouheni paper.pdf Ben Bouheni.F. (2014b): "Banking Governance: Islamic banks vs. Conventional banks", Hanken Centre For Corporate Governance, Finland, 26th February 2014. https://www.shs.fi/banking-governance-islamicbanks-vs-conventional-banks-262-1630-1800

Ben Bouheni.F., Bellalah., M. (2012): “Islamic Banking \& Risk Management :Problems of Islamic Banks and Recommendations", Lambert Academic Publishing, 2012.

Ernst \&Young Report, (2013): "World Islamic Banking Competitiveness Report 2013", Ernst\&Young Fama E. (1985): "What's different about banks?", Journal of Monetary Economics

Greuning. V.H., Iqbal.Z. (2008) “Risk Analysis for Islamic Banks", The world bank Washington, D.C.

Levine, R. (1997) : "Financial Development and Economic Growth: Views and Agenda,\| Journal of Economic Literature, Vol. 35, pp. 688-726.

Levine., R, (2004) : "The Corporate Governance of Banks: A Concise Discussion of Concepts and Evidence", World Bank Policy Research Working Paper 3404.

Macey.J., O'Hara.M. (2003) : “The corporate governance of banks”, FRBNY Economic Policy Review.

Shanmugam, B., Rina,Z. (2009): "A primer on Islamic finance", The Research Foundation of CFA Institute

Shleifer, A., Vishny, R. W. (1997): “A survey of corporate governance”, Journal of Finance.

Zingales, L., (1994), "The value of the voting right: A study of the Milan stock exchange experience", Review of Financial Economics 7, 125-48. 